\title{
Chapter 6 \\ Social Policies and Governance in Geneva: What About Social Innovation?
}

\author{
Patricia Naegeli
}

\subsection{Introduction}

The governance of the Swiss welfare state is marked by the principle of subsidiarity (Bütschi and Cattacin 1993), which favours private initiative before state action and according to which tasks are divided between the three territorial levels: the Confederation, the cantons and the municipalities. The result is multilevel governance (Scharpf 1994), both hierarchically within the state and, in principle at least, horizontally between all the welfare organisations involved (public and private for and non-profit; see Cattacin 1996). Until the mid-1970s, federal social policies and insurance were marginal, social benefits were mostly in the hands of private, subsidised non-profit associations and social insurance was private and mutualised by working sector, ideology or religion. From 1975 to 1985, when other European countries were already cutting social benefits, the federal welfare state caught up and finally normalised its position within the rest of Europe (Cattacin 2006, p. 50). So, if in Switzerland basic social insurance ${ }^{1}$ has been progressively introduced and centralised (Gilliand 1988, pp. 39-58), following the principles of subsidiarity and federalism, the federal state determines through legislation a minimum level of social protection, giving the cantons and municipalities a great degree of freedom to improve and manage their own social policies. ${ }^{2}$ This path dependency (Merrien 1990) results in significant cantonal autonomy and gives rise to huge differences

\footnotetext{
${ }^{1}$ For an overview of the adoption and implementation of social insurance legislation in Switzerland, see Gilliand (1988, p. 58).

${ }^{2}$ In Switzerland, cantons and municipalities have a high degree of autonomy, particularly in areas such as education, healthcare and social policies. As a result, social policies can be very well developed in a canton or kept to the minimum level required by the Swiss Confederation. But it is precisely at the local level (cantons and municipalities) that innovation can be implemented most easily. An example of the division of powers between the federal and cantonal levels in social policy matters can be found in Armingeon et al. (2004, p. 22).
}

P. Naegeli $(\bowtie)$

4, av. du Simplon, 1225 Chêne-Bourg, Switzerland

e-mail: Patricia.Naegeli@unige.ch

(C) The Author(s) 2016

T. Brandsen et al. (eds.), Social Innovations in the Urban Context,

Nonprofit and Civil Society Studies, DOI 10.1007/978-3-319-21551-8_6 
in social benefits throughout the country (Armingeon et al. 2004; Höpflinger and Wyss 1994).

As argued by Cattacin (1996), it is exactly this local autonomy - a result of Switzerland's federal structure, according to which the national territory is divided into 26 cantons - that makes possible innovative social policies at the local level. According to Bertozzi and Bonoli (2003), this cantonal freedom makes it possible to match local social needs and territorialised social policies. In their words:

While the federal structure of the state may have hindered the development of certain social policies, it has also fostered innovation at the local and cantonal levels as well as adaptation with respect to the social needs of territorial units. (Bertozzi and Bonoli 2003, p. 13)

So Swiss cantons should have enough room to manoeuvre to adapt their social policies to particular, territorialised needs. The major question of this chapter is whether this cantonal autonomy, particularly with respect to the governance of the social, really does lead to the implementation of innovative social policies. ${ }^{3}$ As an example, we analyse Geneva, which is known for its comparatively generous social policies (Höpflinger and Wyss 1994, p. 55, IDHEAP/BADAC 2010a, b, c, d, e ${ }^{4}$ ), and which, as a city-canton, ${ }^{5}$ has a particularly large degree of autonomy in determining its social policies. In the case of Geneva, references to the "local level" mostly apply to cantonal measures rather than city ones, for reasons that will appear throughout this chapter. We explore whether Geneva's governance arrangements tend to favour or disfavour innovative social policies and which elements appear to hinder their emergence. As was underlined in Chap. 2 (Cattacin, Zimmer), by governance arrangements we mean the outcome resulting from complex processes that involve a multitude of actors (the state, non-state organisations, the market) and which have to be understood in their context (the institutional context, the context of welfare governance arrangements and the local political culture). It will become clear that Geneva's governance of the social policies, embedded in its context, tends to place the state and its administration, especially state councillors and civil servants, as the legitimate provider of social services. But this state orientation is only possible with

\footnotetext{
${ }^{3}$ What we mean by innovation will be defined later in this chapter.

${ }^{4}$ Statistics on the website of the IDHEAP/BADAC (Institut des hautes études en administration publique/base de données des cantons et des villes suisse) show that the Canton of Geneva, in comparison with the other 25 cantons, has high expenses for culture and social activities $(6.41 \%$ of public expenses, rank 1) and social security (23.18\% of PE, rank 1) (IDHEAP/BADAC 2010a); has the second-highest per capita expenditures, after Basel-Stadt (IDHEAP/BADAC 2010b); has the second-highest income inequality (a Gini coefficient of 0.45) (IDHEAP/BADAC 2010c); has, together with the Canton of Zug, the second-highest number of additional social benefits (IDHEAP/BADAC 2010d); and is the administration with by far the highest number of subdivisions (105 services for 7 departments, rank 1) (IDHEAP/BADAC 2010e). It is important to notice that while Geneva consistently ranks second in many of these measures, the first place is not always occupied by the same canton.

${ }^{5}$ Geneva is both a canton and a city. The Canton of Geneva encompasses 45 municipalities and 476,000 inhabitants in a territory of $282 \mathrm{~km}^{2}$. The city of Geneva is the most important municipality in the canton, with 195,160 residents. Its territory measures $15.9 \mathrm{~km}^{2}$ (statistics for end of 2013). See Swissworld and Département fédéral des affaires étrangères (2014) and Ville de Genève (2014a). It is for this reason that we argue that the city is almost the canton and vice-versa.
} 
the support of non-profit organisations, ${ }^{6}$ which are heavily subsidised and whose demarcation from the public sector is often unclear. Furthermore, the importance of political parties in Geneva's political culture and the influence of the republican model of neighbouring France, where power tends to be concentrated, may partly explain our findings. Economic actors are excluded from this state-orientated welfare system. As a result of these factors, we hypothesise that social innovation is above all incremental and that when it does occur, it does so due to a certain consensus among the implied actors. Indeed, despite political differences, the idea of working against poverty (what stakeholders call "solidarity") seems to be, together with "personal responsibility", the key deep core value, and the necessity of imposing it mostly top-down justifies the state orientation. This basic consensus on this fuzzy concept of "solidarity" was emphasised by our interviewed stakeholders and is in line with our own observations.

This chapter was written within the framework of the European project Welfare Innovations at the Local Level in Favour of Cohesion (WILCO). It includes a wide range of sources: political debates in city council and the cantonal parliament, the political programmes of most important parties, local newspaper articles, grey literature, statistical data provided by the public administration, 12 semi-directed interviews with local stakeholders ${ }^{7}$ and two focus groups to clarify diverging or shared positions regarding local welfare. ${ }^{8}$

The chapter is divided into five parts. First, we will introduce the main challenges in Geneva's governance and identify the general tendencies of its local welfare governance arrangements. Second, its local welfare state and social policies will be situated in the Swiss context. Third, hypotheses concerning Geneva's main actors in the field of social policies will be developed. Sabatier's approach (Sabatier 1991, 1998), which assumes the existence of coalitions of values, and of power relationships between these coalitions, leading to majorities and minorities in specific policy fields, will guide Part $3 .{ }^{9}$ More specifically, emphasising the importance of political parties within these coalitions, the balances of power over the last 20 years will be described. Fourth, an examination of the actual programmes of the main political parties and interviews with local stakeholders will reveal the core values of the local welfare state, while specific issues in the fields of unemployment and

\footnotetext{
${ }^{6}$ By non-profit organisations we mean organisations that provide welfare benefits but which are also an essential " $[\ldots]$ 'public space in civil societies' [...] at the intersection between the state, the marketplace and the informal sector" (Evers 2000, p. 567).

${ }^{7}$ For more information about the interviews, please see footnote 62 .

${ }^{8}$ I would like to thank the following people who have collaborated with me on the WILCO project: Nathalie Kakpo, who did part of the field- and deskwork in Geneva; Sandro Cattacin for his critical and pertinent input; and Maxime Felder for his support and comments during the writing of this chapter. I would also like to thank Christian Jöhr of the Social Service of the City of Geneva, who was a helpful discussion partner regarding concrete issues in the city, and all persons who agreed to be interviewed during this research.

${ }^{9}$ This approach assumes that the cities' policies are influenced by a constellation of actors, namely policymakers, fieldworkers, scholars, civil servants and journalists, who share a common belief system (values, problems and perceptions) and are capable of acting in a coordinated way.
} 
childcare will strengthen our understanding thereof and permit us to define value coalitions. Fifth, we will question Geneva's capacity to innovate in the area of social policies and examine whether its governance of social challenges results in innovative social policies or the preservation of the status quo.

\subsection{Geneva's Challenges: Multilevel Governance and Multiple Territories}

Geneva is part of one of the most dynamic regions in Switzerland, situated at the extreme southwest of the country. Home to several international organisations, an important banking sector and quality business services, as well as world-class research centres, including the European Organisation for Nuclear Research (CERN), Geneva is definitely an important international player in the globalised economy.

This aspect of the "International Geneva", oriented beyond Switzerland's national borders, is emphasised by local stakeholders and Geneva's city marketing and goes hand in hand with its geographical location, which is almost outside the country (Cattacin and Kettenacker 2011). Indeed, Geneva is situated at the very edge of Switzerland, sharing only a $4.5-\mathrm{km}$ border with the rest of Switzerland but a $103-\mathrm{km}$ border with France. ${ }^{10}$ Notwithstanding its economic and international importance, the canton occupies a somewhat marginalised position within the country, and it is common to hear that Geneva is not "really Swiss", whatever that might mean. ${ }^{11}$

This assumption is reinforced by the fact that Geneva's main social challenges are not contained within the logic of borders and concern the whole metropolitan area of 918,000 inhabitants, ${ }^{12}$ namely the Grand Genève, which includes neighbouring France and the Canton of Vaud (District of Nyon). At the end of 2013, cross-border workers, officially defined as "non-Swiss" people who live in neighbouring France and work in Geneva, numbered 68,800. This is one quarter of all the cross-border workers in the country. ${ }^{13}$ It is interesting to note that the high numbers of Swiss who live in neighbouring France, often clandestinely, are not included in these statistics. ${ }^{14}$

Geneva's social challenges are de facto supra-regional, although the logic of governance remains strongly territorialised, confined to the municipal and cantonal levels, as a result of which there is no territorial authority to solve important challenges such as delays in the construction of more public transit, traffic problems and the enormous problem of the lack of affordable housing. This incongruence between

\footnotetext{
${ }^{10}$ Source: Ville de Genève (2014a).

${ }^{11}$ Source: Der Spiegel (1985).

${ }^{12}$ Source: Grand Genève (2014a).

13 (Office cantonal de la statistique — OCSTAT/Département des finances 2013).

${ }^{14}$ In 2009, two out of three new immigrants to France were Swiss (Grand Genève 2014a). But most of them do not declare that they live full-time in France and therefore do not pay taxes where they live, a significant problem for the French municipalities concerned.
} 
the nature of the problems, which are cross-border and regional, and the problemsolving structures, which are strongly territorialised, is not unique to Geneva, of course, and it is especially common in states with different relatively autonomous and powerful levels of government, as is the case in Switzerland. According to Klöti 1985 , p. 13, 17, this situation can result in steering and legitimation problems in urban policies and conflicts of interest between the different levels of government:

That is why urban policies have to be able to handle a conflict of interest between supralocal requirements and local needs. Above all at the level of the agglomeration, there is no authority that can intervene in a regulatory and coordinator manner (Klöti 1985, p. 17).

In the case of Geneva, a Grouping for Transfrontier Co-operation ${ }^{15}$ was officially created in 2012 for the purpose of governing the Grand Genève. It is an autonomous body under Swiss public law with legal personality and its own budget, and it is charged with realising projects within the Franco-Vaud-Geneva conurbation and deal with regional challenges. But uncooperative local authorities and regional governments on both sides of the border confront this grouping and, most importantly, by the rise of the populist MCG (Geneva Citizens' Movement),${ }^{16}$ which leads to an "anti-cross-border workers" attitude, the most recent example of which is the recent popular vote against a cross-border construction project. ${ }^{17}$

While Grand Genève must remain in our minds when we speak about Geneva, this chapter focuses on the Canton of Geneva, which includes 45 municipalities, including its most important, which is of course the City of Geneva. ${ }^{18}$ Geneva's unusual way of doing politics and governing its "small" territory, where the canton is almost the city and vice versa, is often pointed out by other parts of the country, which more or less explicitly criticise Geneva's multilevel governance, where no one really knows "who does what" and that "wouldn't exist if Geneva weren't so rich", as stated in a Bernese newspaper article (Chapman 2012).

Indeed, the same newspaper article refers to a crucial point in Geneva's multilevel governance - disagreements between cantonal and city governments on important political issues - and the ability to block important (cantonal or city) projects by exercising the municipal or cantonal right to a veto, for instance, for construction projects, not least because of NIMBYism. ${ }^{19}$ While tensions often crystallise between the city and the canton, the canton's 44 other municipalities also represent

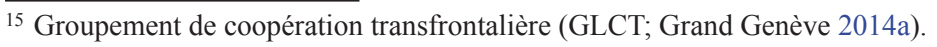

${ }^{16}$ In Part 3, we will discuss birth and rise of this political party.

${ }^{17}$ In the aftermath of the Swiss popular initiative on 9 February 2014 (accepted by $50.34 \%$ of voters), which requires the introduction of immigration quotas ( $60.9 \%$ of Geneva's population voted against it), the canton's population voted against financial participation in a cross-border parking construction project, following the arguments of the MCG, which is opposed to any financial investment on the "French side" (De Weck 2014; La Tribune de Genève 2014).

${ }^{18}$ For more details, please refer to footnote 5 .

19 "More formally, Not In My Back Yard (NIMBY) refers to the protectionist attitudes of and oppositional tactics adopted by community groups facing an unwelcome development in their neighbourhood" (Dear 1992, p. 288); see also Kübler (1995), who analysed these kinds of strategies in the field of urban drug policies.
} 
important political and financial constraints, even if their powers and financial resources are less important than in other Swiss cantons. ${ }^{20}$ The consequence is that important projects may be paralysed, sometimes for decades, ${ }^{21}$ which is evidence for the argument that Geneva is stuck in a joint decision-making trap (in the sense of Scharpf 1985) that makes it difficult, because of cantonal or municipal "veto coalitions" (Czada 2003, p. 183), to overcome the status quo. According to Czada, a government's ability to solve (social) problems rapidly (Czada 2003, p. 197) depends on the interplay of three dimensions: the degree of agreement between political parties, the degree of corporatism and the nature of constitutional veto structures. In his opinion, Swiss democracy compensates for the threat posed by potential vetoes by producing strong legislative majorities, which has resulted in a political landscape that has been stable for many years. But this stability can also be endangered, as has been the case in Geneva (see Part 3 on the evolution of political forces). Furthermore, difficulties related to multilevel governance also interfere with what we call the governance of the social and the provision of social services and benefits. Indeed, overlapping services between cantonal, city and municipal administrations, coupled with the multiplicity of private, above all non-profit, organisations, makes it difficult to even identify governance arrangements and service providers in this sector. The analysis of 120 qualitative interviews of vulnerable migrants who were or had been in touch with local welfare services in the 20 cities of the WILCO research $^{22}$ indicates clearly that a multitude of (overlapping) services significantly discourages (vulnerable) people from claiming social benefits and leads to mistrust of the public administration (Cattacin and Naegeli 2014). ${ }^{23}$ Furthermore, services have also been criticised for not being able to address complex life situations resulting from intersecting problems, which may increase the risk of multiple discrimination (Hankivsky and Cormier 2010).

In Geneva, duties have been split between the canton, which is responsible for individual social assistance, and the municipalities, which are responsible for "communitarian" and collective problems. For instance, the canton provides basic financial and individual social assistance through the Hospice Général, an autonomous public institution that was created in 1535 and is mandated by the canton. ${ }^{24}$ These financial benefits are sometimes supplemented by the City of Geneva through its own Social Service, meaning that a resident of the City of Geneva may receive a greater social allowance than someone who resides in another municipality within

\footnotetext{
${ }^{20}$ According to a newspaper article, the allowed budget for the municipalities constitutes less than $20 \%$ of all public expenses in the canton, which, according to Mabut (2014), is very low for Swiss municipalities.

${ }^{21}$ For example, after 50 different proposals since the nineteenth century, plans to create some kind of link between the two shores of Lake Geneva (traversée de la rade) have still not been implemented. See, for instance, Francey (2014).

${ }^{22}$ For a description of the research, please refer to footnote 7.

${ }^{23}$ If we add mistrust of public administrations to the mentioned overlapping services, which result in the feeling that one is lost in a labyrinth of welfare organisations, it is easy to understand why vulnerable people (in this case vulnerable migrants) may simply avoid claiming social benefits.

${ }^{24}$ In the Swiss context, this is an exception; social assistance is usually provided by municipalities.
} 
the canton. Furthermore, the municipal Social Service works from the perspective of proximity to and the prevention of social problems and has developed a territorialised "communitarian" approach that aims to reinforce social cohesion. ${ }^{25}$ As a result, a multitude of actors constitute a labyrinth of local welfare organisations, mostly non-profit organisations. Aware of the overlapping public services between the canton and the city, the current cantonal government has decided to disentangle its duties from those of its 45 municipalities (Mabut 2014; Moulin 2014), a task that it wants to complete in close cooperation with the Association of the Municipalities of Geneva and its representatives. A first technical report has just been published (Groupe de travail technique (GTT) 2014), whose purpose is to assess the current situation. According to this report, there are 12 main areas in which there is significant overlap, including social services, where it is not always clear which duties belong to the municipalities and which to the canton because "the distinction between these two fields of public action is difficult to make, because every community social action aims finally to improve the social and economic situation of individuals" (Groupe de travail technique (GTT) 2014, p. 8). ${ }^{26}$

Our interviews with 12 local stakeholders and two focus-group discussions have shown a relatively clear consensus in the political arena regarding the necessity of keeping a strong local welfare state and on the view that it is the responsibility of the state (and e.g. not the private sector) to help vulnerable people. We may assume that this state-oriented welfare mix ${ }^{27}$ is specific to Geneva in Switzerland, which is known to correspond to a hybrid conservative-corporatist model with liberal tendencies, according to the classical typology of Esping-Andersen (1990, pp. 74-77), or to constitute a "compromise between Liberalism and Socialism" (Möckli 1988, p. 27). Indeed, for a long time the Swiss welfare state has been considered a welfare laggard (Bonoli and Mach 2000, p. 140), especially regarding health insurance (which only became compulsory in 1996), family policy and long-term unemployment benefits. But this welfare laggard reputation has to be taken with a grain of salt. Indeed, Möckli (1988, pp. 24-25) has shown the pioneering character of some social and political laws, for instance, laws regarding the social protection of children in factories $(1815)^{28}$ and the first Swiss factory law of 1877 , which introduced

\footnotetext{
${ }^{25}$ One of the innovations selected for study by the WILCO project was one of the organisations involved in implementing this "communitarian" work at the city level, namely the UAC (Union for Community Action), which is located in four areas of the city and whose principal aims are to connect relevant associations with interested civil-society participants and, therefore, to reinforce collective action through better coordination and networking (City of Geneva 2014).

${ }^{26}$ Original quotation: "La distinction entre ces deux champs d'action publique pour sa part reste malaisée, toute action sociales communautaire visant au final à l'amélioration de la situation sociale ou économique d'individus" (Groupe de travail technique (GTT) 2014, p. 8).

${ }^{27}$ By welfare mix, we mean the interplay of public and private (non- and for-profit) organisations in the steering, planning and providing of social welfare services, or "the combination of different actors and sectors involved in coproducing welfare programs, services and/or goods" (Oosterlynck et al. 2013, p. 19). To examine the welfare mix is also to examine the diversity of the organisations involved.

${ }^{28}$ The two pioneering cantons were Zurich and Thurgau, which were the first jurisdictions in Europe to pass legislation in favour of child labourers in factories, although it did not have any
} 
the 11-h day, pioneering legislation for continental Europe. And more recently, as Cattacin (2006, p. 49) has demonstrated, the 1970s were a decade of growth for the Swiss welfare state, in contrast to other European states, which had already begun cutting their social spending by then. Furthermore, the specificities of federalism result in complex cohabitations between public and private structures, between the state, the economy and civil society (Cattacin 2006, p. 50), which can lead to the belief that the welfare state at the federal level is weak. But the author underlines that today the Swiss federal welfare model, rather than being an exception, has become an international reference point for individualisation and activation processes:

The transformations of welfare pluralism in Switzerland in recent years have resulted in the fact that it no longer is an exception, retarded, particularly complex or catching up, or reveals a counter-tendency, but has instead become an international reference point for the individualisation of responsibilities, the activation of citizens and even the strengthening of incentives and the moderation of the different welfare providers (Cattacin 2006, p. 69). ${ }^{29}$

Also, Swiss pensions and unemployment benefits tend to be generous in comparison with those of other European countries (Bonoli and Mach 2000, p. 140). As regards innovative and pioneering social policies, in short, Geneva once had the reputation of having both.

\subsection{Pioneering Local Welfare State?}

According to a newspaper article in the Neue Zürcher Zeitung, Geneva was once "a future-oriented laboratory for Switzerland [...]" (Büchi 2012). It was the first canton, together with the Canton of Vaud, to introduce the right to vote for Swiss women in 1959, long before it was introduced at the federal level in 1971 and in other cantons. According to the same article, Geneva also had progressive urban planning and the most generous social policies of all the cantons, thanks to its expanding financial sector. But the article also claims that Geneva's potential for innovation has run its course, and that "today, the Republic of Geneva is only a shadow of its former self” (Büchi 2012).

Even if it seems true, at first glance, that Geneva has actually lost its force to propose future-oriented projects and policies, some recent examples regarding Geneva's pioneering ${ }^{30}$ social policies can still be found. Indeed, in 1991, Geneva was

impact (Möckli 1988, p. 24).

29 Original quotation: "Les transformations du welfare pluralism en Suisse durant ces dernières années en font aujourd'hui non plus un cas exceptionnel, retardé, particulièrement complexe ou encore en récupération en contre tendance, mais une référence internationale en ce qui concerne l'individualisation des responsabilités, l'activation des citoyens ou encore l'incitation et la modération des acteurs producteurs de bien-être" (Cattacin 2006, p. 69).

${ }^{30}$ Of course, what is pioneering in a certain context is not necessarily so in another. In this example, the context is the Swiss Confederation. We will return to this point when defining precisely what we mean by social innovation. 
the first and only canton to introduce the right for undocumented children to go to school (Halle 2011). In 2001, it implemented maternity leave at the cantonal level, while it was only adopted federally in 2005 , exactly 60 years after a right to maternity leave at the federal level was inscribed in the constitution, and this only after having been rejected four times by popular vote. Even so, federal maternity leave benefits are quite minimal -14 weeks of paid maternity leave at $80 \%$ of the last salary - and address only working mothers or those who are at least registered with the unemployment office.

This example illustrates the function of the federal state: It intervenes only when it has to fulfil shortcomings in cantonal regulations and when broad coalitions at the national level demand its support to implement social policies that are not developed enough at the cantonal level (Cattacin 1996). Indeed, as said before, social policies are mainly managed at the cantonal and city levels, the three levels - federal, cantonal and municipal - cohabitating in multilevel governance, based on the constitution and history of the Swiss Confederation, which is directly linked with the principle of direct democracy, and which itself requires negotiations between all actors that could potentially, and easily, launch a referendum against new laws. The path dependency characteristic of Switzerland ${ }^{31}$ - the decentralisation or rescaling of social policies - seems to be common to most European countries, according to Kazepov:

As a reaction to the crisis of the welfare state, reform processes - in their double meaning of vertical and horizontal subsidiarisation - produced a steady shift from a vertical towards a horizontal coordination of social policies, which finds its ideal level of implementation in the local dimension. Despite the fact that these tendencies are common to most European countries, the development and institutionalisation of the new governance arrangements do not converge. On the contrary, the results of these processes of change seem to produce a territorially structured diversification [...]. This diversification varies according to socio-economic context and institutional arrangements, with all the specificities this might entail: from a high degree of freedom of the Comunidades Autonomas in Spain, the Länder in Germany or the Cantons in Switzerland, to the relatively low intranational differentiation in France (Kazepov 2010, p. 49).

But this cantonal jurisdiction over social policy does not explain why Geneva's social policies often exceed the minimal federal level and tend to be generous by Swiss standards. In their article "Swiss Worlds of Welfare" (Armingeon et al. 2004), the authors explain the significant variation in cantonal welfare regimes by socioeconomic variables and above all by the degree of urbanisation, which seems to be positively correlated with the election of left-wing parties, which favour a stateoriented welfare policy. According to the authors:

\footnotetext{
${ }^{31}$ The Swiss Constitution, which was adopted in 1874, did not grant any jurisdiction over social policies to the federal state. In 1890, a popular vote made it constitutionally possible for the first time for the Swiss Confederation to create national social policies through legislation. This vote was a key moment in the establishment of a national welfare state, which became increasingly powerful. This constitutional change resulted in the adoption in 1911 of the first national health and accident insurance (implemented in 1914 and 1918, respectively), and in the adoption of the old-age pension in 1946 (implemented in 1948). See (Gilliand 1988, pp. 55-57) for details.
} 
Urbanisation is obviously a major socio-economic explanatory variable for cantonal social security systems. Left-wing power is strongly and positively correlated with urbanisation (0.64): the more urban a canton, the higher the share of left-wing parties in government. On the other hand, the more rural a region, the better the odds for centrist parties (correlation with urbanisation: - 0.54). In contrast, the power of right-liberal government is not significantly related to urbanisation. Hence, one could argue that urbanisation is the major background variable explaining both worlds of welfare and the political strength of the left in Swiss cantons (Armingeon et al. 2004, p. 39).

Accordingly, Geneva's high degree of urbanisation should tend to favour leftwing parties and could therefore explain the state-oriented development of social policies. Moreover, Armingeon et al. (2004) categorise the Canton of Geneva as a social-democratic regime for three out of four of their selected variables, ${ }^{32} \mathrm{em}$ phasising that it is one of the only cantons to possess a somewhat coherent welfare regime. It is also the only one that can be classified as social-democratic in the country (Armingeon et al. 2004, pp. 34-35).

\subsection{Actors and Power Relations Around Social Policies}

These interrogations raise the question of who are the actors who define social policies and the values behind them. According to Neidhart (1970, pp. $287 \mathrm{ff} ., 294$, 313 ) and Kriesi and Jegen (2001), direct democracy implies that political projects are largely debated in the administrative or pre-parliamentary arena and that these debates have to integrate negotiations from all kinds of actors to avoid the launching of a referendum against the proposed law or project. So direct democracy often implies the finding of a consensus between the implied actors, and sometimes, when the debate is very conflictual, we can speak about a compromise rather than a consensus. According to Sabatier $(1991,1998)$, the actors are constituted in competing advocacy coalitions ${ }^{33}$ within a policy subsystem ${ }^{34}$ that share a common belief system organised around core values and secondary aspects. Within the core values, he

\footnotetext{
32 The four variables are employment, education, taxation and social security.

33 "An advocacy coalition consists of actors from many public and private organizations at all levels of government who share a set of basic beliefs (policy goals plus causal and other perceptions) and who seek to manipulate the rules of various governmental institutions to achieve those goals over time" (Sabatier 1991, pp. 151; 153). These coalitions develop power relations, which result in the emergence of majorities and minorities. Another definition is provided by Kriesi et al. (2006, p. 342): "[...] at a given moment, in a given subsystem, we are likely to find a limited number of coalitions with varying influence on the political processes within the subsystem. [...] Coalitions can be composed of one type of actor only (homogeneous), or they can incorporate different actor types (heterogeneous)."

34 "A subsystem consists of actors from a variety of public and private organizations who are actively concerned with a policy problem or issue, $[\ldots]$ and who regularly seek to influence public policy in that domain" (Sabatier 1998, p. 99).
} 
distinguishes the deep core, meaning fundamental normative and ontological axioms, from the policy core, which are the strategies used to achieve the core values. Furthermore, Sabatier argues that the coalitions and core values remain relatively stable for a decade or longer and are therefore difficult to change. So policy learning most often only applies to the secondary aspects, which comprise a multitude of instrumental decisions that are necessary to implement the policy core. Kriesi et al. (2006, pp. 342-343), building on Sabatier's theory regarding advocacy coalitions and the power distribution between them, add the idea of a relational perspective on the policy process. According to this theory, power is either fragmented or concentrated, and the type of interaction is characterised by the predominance of conflicts, bargaining or cooperation.

Of course, these policy-specific power structures are determined by the macropolitical context, meaning, among other things, the extent to which political actors are induced to co-operate informally (related to the distribution of power) and the policy phase, assuming that the type of interaction becomes more conflictual in critical policy phases. The power relations vary from one policy domain to another. According to Kriesi et al. (2006), Switzerland's distribution of power is clearly fragmented and interaction tends to be cooperative rather than conflictual. But this does not mean that consensus democracies cannot be conflictual or bargaining as well, depending on the political issue involved.

Based on these theoretical findings, we assume that in Geneva, with respect to direct democracy and the welfare mix, which includes by necessity a fragmentation of power, state actors (state/city councillors and the related civil servants, often themselves members of political parties) and political parties are the dominant actors in determining local welfare policies. Therefore, they have a strong impact on defining the welfare state's core values. If, following the principle of subsidiarity, non-profit organisations play an important role in welfare provision and are part of the debate, we expect their core values to largely be in line with those of the state, not least because of the important state subsidies they receive. In other words, we hypothesise that the above-mentioned groups dominate the advocacy coalitions that shape the core values of social policies, and that their goal in public debate is to link themselves with state-oriented welfare services, which develop from the values defined by them. In turn, we assume that the presence of this "strong" welfare state legitimises the predominance of political parties and state actors in public debate, leading to a sort of virtuous circle in which fundamental changes in values, and therefore in policies, are difficult to make. Following this logic, we assume that policy innovation therefore tends to be incremental, remaining within the existing logic of state orientation.

Finally, we may also attribute the predominance of political parties and stakeholders from the public administration to the influence of neighbouring France, where power is more centralised. In this sense, Geneva presents a certain concentration of power and conflictual and ideological debates between political parties that 
challenge state-centred administration and its stakeholders, sometimes leading to political deadlock. ${ }^{35}$

Following these assumptions, it is first necessary to examine the development of political forces in Geneva over the past two decades. We may then apprehend the core values of the local welfare state, especially in the fields of unemployment and childcare.

\subsubsection{Canton of Geneva: From Two Coalitions to Three (and a Half)}

As said before, Geneva has two elected assemblies: a cantonal parliament and a city council. ${ }^{36}$

The cantonal parliament (Grand Conseil) comprises 100 members who are elected by popular vote for 5 years,${ }^{37}$ according to a proportional-representation electoral system. At the city level, the 80 members of the city council (Conseil Municipal) are elected every 4 years. There has been an important evolution in the constellations of power within these two legislative bodies over the past two decades. Regarding the composition of the Grand Conseil, between 1993 and 2001, there were only two (mutually opposed) coalitions: the Entente (centre-conservative parties, including the Liberals, the Radicals ${ }^{38}$ and the Christian Democratic Party) and the Alternative (left-wing parties, including the Socialists, the Greens and the Labour Party, the latter becoming the Left Alliance ${ }^{39}$ between 1993 and 2001). Traditionally, except in

\footnotetext{
${ }^{35}$ Examples of political deadlock are the linking of the two shores of Lake Geneva (footnote 22) and the expansion of the main railway station, which provoked lively debates and mobilised the inhabitants of the area behind the railway station; see, for instance, Pasteur and Armanios (2011). But also in Geneva, there is a desire for more political pragmatism and less ideology. One example is the recent cross-party group, which includes members of all political parties except the Swiss People's Party (UDC), to start a pilot project to regulate the consumption of cannabis through Cannabis Consumer Associations; see, for instance, Zünd (2014).

${ }^{36}$ Of course, all the other 44 municipalities also have their own city councils.

${ }^{37}$ The mandate can be renewed indefinitely. Before the introduction of the new cantonal constitution in 2013 (accepted in October 2012), members were elected for 4 years (République et canton de Genève 2012a, Arts. 80-81; Arts. 101-102).

${ }^{38}$ The Liberal Party and the Radical Party merged and became the Liberal-Radicals in 2013, after having lost four seats in the 2009 elections (Office cantonal de la statistique-OCSTAT/Chancellerie d'Etat 2013a).

39 The Labour Party sat in the cantonal legislature from 1945 to 1989. In 1989 it was renamed the Left Alliance and gathered various far-left coalitions (for instance Solidarités and Independants). The party changed its name again in 2005 to the Ensemble à Gauche. It continues to group various far-left coalitions and sometimes struggles with internal divisions. Together with the Greens and the Socialists, it constitutes the so-called Alternative, in opposition to the Entente. It is interesting to note that the Ensemble à Gauche was absent from the cantonal legislature between 2005 and 2013. For more information, see the official statistics of the canton (Office cantonal de la statistique-OCSTAT/Chancellerie d'Etat 2013a).
} 
the 1997 election, ${ }^{40}$ the centre-conservative parties have always held a majority in the cantonal legislature. But since 2001, the legislature has also included the clearly right-wing Swiss People's Party ${ }^{41}$ (UDC: Union Démocratique du Centre), and from 2005 on the Geneva Citizens' Movement (MCG: Mouvement Citoyen Genevois), which bases its programme on the protection of Geneva's residents from the "invasion" of cross-border workers. This new party made a dramatic entry. Between 2005 and 2013, it increased its seats from 9 to 20, and it also placed one member in the cantonal executive in 2013. The fact that the MCG shared a common list for the elections of the 2013 executive with the far-right UDC allows us to assume that it lies at the right end of the political spectrum, even though it claims to be "neither right nor left", ${ }^{42}$ a dichotomy that it claims is "history" and is perpetuated by political parties that do not respond to the needs of Geneva's population.

So, regarding the cantonal parliament, we can speak about the end of an era of polarisation between left (Alternative) and centre-conservative parties (Entente), in favour of the existence of three or even four groups and a situation in which there is no longer any clear majority, and where the "historical parties" have to compete with far-right and populist parties, the latter (MCG) alternating between right and left ideologies, depending on the issue. ${ }^{43}$ Overall, the right is more powerful in parliament. ${ }^{44}$

The cantonal executive ${ }^{45}$ is also dominated by representatives from the centreconservative and right-wing parties. Except after the 2005 election, when four members of the Alternative ${ }^{46}$ faced three members of the Entente, the executive has always been right wing. As mentioned before, what was new in the 2013 elections was the election of one member of the MCG, placing the two members of the Alternative (one Socialist and one Green) in a very marginalised position.

The cantonal governance of Geneva historically has always been consistently conservative, a stability that is currently being challenged by the presence of the self-styled "non-determined" populist party MCG. At city council, however, until 2011 the forces were exactly the opposite.

\footnotetext{
${ }^{40}$ In 1997, the Alternative won a majority with 51 of the 100 seats (Office cantonal de la statistique-OCSTAT/Chancellerie d'Etat 2013a).

${ }^{41}$ The translation of the Union Démocratique du Centre as the Swiss People's Party follows the party's original name, which is Schweizerische Volkspartei.

42 "Neither left nor right" (MCG-Mouvement Citoyen Genevois 2014b).

${ }^{43}$ Some argue that the MCG is on the left on social issues and on the right on security, European and immigration issue (Favre 2013).

${ }^{44}$ Composition of the Geneva cantonal parliament 2013: Entente 35, Alternative 34, UDC 11 and MCG 20 (Office cantonal de la statistique-OCSTAT/Chancellerie d'Etat 2013a).

${ }^{45}$ The cantonal executive is composed of seven state councillors who are elected directly by the population by majority vote. Since the 2012 change to the Geneva Constitution (entered into force in 2013), they are elected for 5 years. One member is designated president for the whole period and is the head of the newly constituted presidential department. The other six members are each in charge of a specific department (République et canton de Genève 2012b).

46 Two Socialists and two Greens for one Radical, one Liberal and one representative of the Christian Democratic Party (Office cantonal de la statistique - OCSTAT/Chancellerie d'Etat 2013b).
} 


\subsubsection{The City of Geneva: From the Dominance of the Left to Complex Coalitions}

From 1995 to $2011,{ }^{47}$ the Alternative held an absolute majority in Geneva's city council. It is interesting to note that in 1999, the Left Alliance, a coalition of far-left parties, was the most important party in city council, before the Socialists, which are the most important party today, followed directly by the Liberal-Radicals. As in the cantonal parliament, city council is no longer composed of its two opposite coalitions (Entente and Alternative); instead, since 2003, and especially since 2011, it has also included the two "newcomers": the Swiss People's Party ${ }^{48}$ (UDC, far right) and the Geneva Citizens' Movement (MCG). So, since the 2011 election, with 39 of 80 seats, the Alternative has been just shy of an absolute majority and is obliged to seek some alliances outside of its long-term coalition, for instance with the MCG or the Christian Democratic Party (PDC), which can sometimes tilt the balance towards their political preferences. As in the canton, the minority parties have the power to tilt the balance between the two "traditional" coalitions, if we assume that the latter vote as a bloc in accordance with their parties' instructions. As we will see below, however, things are not always that simple: Internal conflicts (above all within the far-left coalition) and moving coalitions depending on the policy issue involved are affecting the stability of the established coalitions.

At the executive level, things are more stable. From 1991 to 2011, the left had a majority - three out of five seats between 1991 and 1999, and four out of five between 1999 and 2011. ${ }^{49}$ So we have to keep in mind that the executive's majority is no longer the same as that of the city council on which it relies, which creates additional tensions and sometimes causes political debates to take a long time when the issues are conflictual. One current example is the finally accepted renovation of Les Minoteries, a complex of 329 subsidised apartments owned by the city whose maintenance has been neglected for the past 40 years. The executive proposed a renovation of 90 million $\mathrm{CHF}$ (about 72 million $€$ ). The proposal was rejected twice

\footnotetext{
47 Composition of the city-council coalitions from 1991 to 2011. 1991 Entente 40, Alternative 40; 1995: Entente 36, Alternative 44; 1999 Entente 36, Alternative 44; 2003 Entente 27, Alternative 44, UDC (far right) 9; 2007 Entente 29, Alternative 42, UDC 9; 2011 Entente 22, Alternative 39, UDC 8, MCG (populist) 11 (République et canton de Genève 2014).

${ }^{48}$ In fact, the Swiss People's Party (UDC) may be new in Geneva, but it is well established in the Swiss-German part of the country, being the predominant party in several regions. For an analysis of this party, see Mazzoleni (2008).

${ }^{49}$ Executive, City of Geneva: 1991 Liberals 1, Radicals 1, Socialists 1, Greens 1, Labour Party 1; 1995 same as in1991, but instead of Labour Party, Left Alliance; 1999 Liberals 1, Socialists 1, Labour Party 1, Left Alliance 1; 2003 same as 1999. 2007 Radicals 1, Socialists 2, Greens 1, À Gauche Toute 1 (new name for the Left Alliance); 2011 same as 2003, but À Gauche Toute became Ensemble à Gauche (Together on the Left). In 2012 a by-election replaced the radical magistrate with a member of the Christian Democratic Party (PDC). Note that the composition of the Left Alliance/Labour Party and its name changed for every election, so we can assume that the Left Alliance's coalition is not stable at all. Source: (Office cantonal de la statistique - OCSTAT/Chancellerie d'Etat 2012).
} 
by city council, and debates have been heated between the Alternative, which favoured the renovation and the rest of the council (Entente, UDC and MCG), which was opposed, principally because of the cost, demanding for a third time that the project be scaled down. Finally, a narrow majority accepted the renovation. ${ }^{50}$

\subsection{Core Values and Strategies in the Political Arena}

During these lively debates, the different parties' core values become clear, as they do in the different party programmes ${ }^{51}$ and in our interviews and focus groups. We will focus on the core values regarding the local welfare state and specify the coalitions that have emerged for specific policy issues. Unemployment ${ }^{52}$ and childcare will serve to illustrate concrete policy orientations.

\subsubsection{More or Less State Intervention?}

In Geneva, core oppositions between political parties regarding the local welfare state are transforming the importance of the state, the fields of its interventions and how far its contributions are expected to go. It is not surprising that the more the parties can be categorised as being "on the left", the more the state's intervention is legitimated. For the Socialists, the state has a crucial role to play in the construction of society, which is based on solidarity, a society of opportunities and equalities, not of privileges. Other notions such as redistribution, access to public services, gender equality and jobs for all are the core values (deep core) indicated in their 40-page programme for the 2013-2018 cantonal legislature. ${ }^{53}$ The Left Alliance's policies are similar, but it emphasises class struggle and advocates policies that

\footnotetext{
${ }^{50}$ The third and final debate took place on 25 March 2014 at City Hall. These debates are always broadcast by Léman Bleu, the local television channel. The renovation project was finally accepted by a vote of 38 (the Alternative and two Independents) to 36 (Entente, UDC, MCG, the conservative, far-right and populist parties). There was one abstention (a member of the Greens), see Dethurens (2014).

${ }^{51}$ Cantonal and city party programmes being identical, no distinction between the two levels has to be made.

52 In Switzerland, the economic crisis at the end of the 1980s marked a turning point regarding unemployment policies. In 1995, following the recommendation of the OECD Making Work Pay (Giraud 2007, p. 96), the Federal Unemployment Law was revised in the direction of workfare, activation, reciprocity and increased control over the unemployed. But this logic has been implemented in different ways in different cantons. In Geneva, for instance, the focus has been on reintegration or even inclusion rather than control (Giraud 2007, p. 100). Since 1995, the cantons have had to fill the gap left by the reduction of federal assistance and implement social-assistance measures for the long-term unemployed who have exhausted their unemployment benefits, a new phenomenon in the country.

${ }^{53}$ Party Programme of the Socialist Party of Geneva, 2013-2018 (Parti socialiste genevois 2013).
} 
are more radical and require maximal state intervention, for instance in matters of housing, childcare, unemployment and redistribution. ${ }^{54}$ For the Greens, the third traditional partner of these two parties, state intervention has to integrate the notion of sustainability. ${ }^{55}$ So all three parties propose greater redistribution and take on the wealthy in the canton, which, they claim, do not contribute as much as they should to public expenses. A shared value of this coalition is that the state should be the main regulator and provider of social services.

For the conservative and far-right parties, in contrast, state intervention should be kept to a minimum and bureaucracy and state expenses must be reduced (Radical-Liberals and Swiss People's Party), or their increase has to be controlled (Christian Democratic Party), overlapping public services at the cantonal and federal levels have to be eliminated and public administration and civil servants have to be re-evaluated. Notions like liberty, responsibility, solidarity, equality in rights and duties and prosperity are deep core values for the Liberal-Radical Party, ${ }^{56}$ while the Christian Democratic Party prefers a welfare mix, where non-profit organisations are seen as more able to solve social problems than the state ${ }^{57}$ but for-profit organisations are also understood to be essential for the well-being of society. All the three parties propose tax reductions. The MCG proposes that social welfare be maintained, but at the same time underlines the necessity to combat social fraud ${ }^{58}$ (this last point is crucial for the UDC too). It has also adopted the slogan "Geneva first", which is common among far-right and populist parties. ${ }^{59}$

From these party programmes, the differences between the political parties appear insurmountable, and we wonder how it is possible for Geneva to continue to have a "strong" welfare state with more social benefits than other cantons, as was

\footnotetext{
${ }^{54}$ In their programme, we can find phrases such as "social resistance", "block the antisocial and antipopular politics of the right and far right" and "stop employers' abuses" (Solidarités Genève 2013).

${ }^{55}$ See Les Verts Genevois (2013).

56 "The Liberal-Radical Party rejects the principle of assistance, rampant statism and all attempts at levelling on the basis that they kill personal initiative, the satisfaction derived from effort and work, entrepreneurship and exploration, all of which it promotes" (Les Libéraux-Radicaux de Genève-PLR 2013, p. 6). Original quotation: "Le PLR rejette le principe d'assistanat, l'étatisme rampant et toutes les tentatives de nivèlement par le bas qui tuent l'initiative personnelle, le goût de l'effort et du travail, la volonté d'entreprendre et d'explorer, qu'il promeut."

57 "Indeed, the PDC believes that associations are the most effective way of promoting the politics of solidarity." Original quotation: "En effet, le PDC considère que les associations sont les plus à même de mener des politiques de solidarité" (Parti démocrate chrétien Genève 2013).

${ }^{58}$ Point 3 of the political charter of the party (MCG - Mouvement Citoyen Genevois 2014a).

${ }^{59}$ For analyses of extreme-right movements in Switzerland, see Skenderovic and D'Amato (2008) and Skenderovic (2009).
} 
emphasised in the field of unemployment by the head of the Solidarity jobs ${ }^{60}$ at the Cantonal Office for Employment, during his interview. ${ }^{61}$

In my sense, this is rather unique in Switzerland: we are the only canton that has so many important additional cantonal welfare measures, at the cost of about 60 million $\mathrm{CHF}^{62}$ that are not covered by the LIASI. ${ }^{63}$ This is real, the human part of Geneva. And there is the real will of a canton-city to have a politics that reintegrates people (iIII, p. 8).

But if we look more attentively at the core values that are mentioned in the party programmes and also by our interviewed stakeholders, we can also see shared deep core values, characterised by notions like solidarity, humanism, individual responsibility, respect for people and equal access to social opportunities. But with respect to the policy core, meaning the strategies used to attain the identified deep core, and even more the secondary aspects, we notice significant differences that correspond to classical right- and left-wing dichotomies regarding the role of the state, its legitimate fields of intervention and, consequently, the amount of public taxes that have or do not have to be spent in these fields.

This agreement about deep core values, sometimes accompanied by a massive divergence in the policy core, is particularly pronounced in the fields of childcare and unemployment.

\subsubsection{Childcare and Unemployment: State Versus Mixed Solutions}

In the field of childcare, all parties except the Swiss People's Party agree that there are insufficient numbers of childcare places available in the city and the canton.

\footnotetext{
${ }^{60}$ Solidarity jobs are jobs in the secondary labour market that are subsidised by the canton and target the long-term unemployed, are implemented by the Cantonal Office for Employment and were legitimised by popular vote in December 2007 (68.5\% in favour), see (République et canton de Genève 2007). While the Socialists and Greens agreed with the law, the far left, including trade unions, fought against it with the argument that it would result in downward pressure on wages and the use of cheap labour for public-administration jobs. Seven years after its introduction, debates on the issue remain heated, and there is increasing opposition to Solidarity jobs, including from the current socialist mayor of the city. See Syndicat interprofessionnel de travailleuses et travailleurs (Sit) (2013) and Salerno (2013).

${ }^{61}$ As indicated above, 12 semi-directed interviews were conducted in Geneva with local stakeholders during the WILCO research (see footnote 7) with a view to understanding their positions and core values regarding unemployment, childcare and housing, but also the local welfare system. The following topics were discussed in the interviews: the main problems and solutions in these areas; the reasons for a need to act, coalitions and the main differences between the stakeholders and between the parties in their positions and reasons for the importance or unimportance of the local welfare system. The analysis of the interviews is based on the actor-centred-institutionalism approach (Mayntz and Scharpf 1995; Scharpf 1997).

${ }^{62}$ About 49 million $€$.

${ }^{63}$ The cantonal law regarding social assistance and social inclusion.
} 
There is a fundamental agreement about the need to increase the number of childcare places, the legitimacy of childcare outside the family and the idea of the social investment state ${ }^{64}$ But the strategies the parties advocate to attain this aim differ, the left advocating public childcare places, funded by public taxes and standardised by public regulations and norms, including qualification criteria for its personnel, the far-right and conservative parties demanding more of a welfare mix with public-private partnerships, enterprise nurseries, nannies, etc., and less state regulation.

Regarding unemployment, coalitions are moving regarding secondary aspects. Traditionally, right-wing parties advocate individual responsibility and claim that it is up to the individual to adapt to structural changes in the labour market and make the main effort to (re)integrate. By contrast, left-wing parties stress structural problems, the inadequacy of the jobs on offer, and the need to reform the labour market itself, for instance by adapting it to help resolve long-term unemployment by creating a subsidised labour market for some employment areas, as was the case with the Solidarity jobs. So while the core legitimacy of the Solidarity jobs was not really questioned, the concrete application caused lively debates and disagreements inside the leftist coalition itself, mostly regarding the type of contracts and the pay. Finally the far left (including the trade unions) was and continues to be opposed to the Solidarity jobs, criticising their tendency to reduce wages and their poor working conditions. Surprisingly, the conservative and far-right parties (and the employers' association) accepted the idea, not without difficulty, of creating this secondary labour market for long-term unemployment, but only under certain circumstances (salary below the market prices, no competition with the private sector).

These two examples show us that political parties agree on the fundamental deep core of the existence of a local welfare state, which guarantees protection and help in case of need. Conflicts therefore revolve around the amount of financial assistance, for instance, or who the provider of the services should be. But we may assume that the shared deep core values are relatively stable ${ }^{65}$ and that discussions and consensus or compromise occur with respect to the policy core and especially secondary aspects.

As stated above, debates take often place in pre-parliamentary arenas, as a result of which coalitions also include non-state actors. According to the previously quoted head of the Solidarity jobs, the creation of these jobs was a real partnership. Before the law was passed, we had people around the table who were in favour or against. We reflected together on what the legislation should look like. It was a first in terms of partnership (iIII/p. 8).

This partnership between different stakeholders seems to indicate that political parties and civil servants in the public administration have to take associations (for

\footnotetext{
${ }^{64}$ For a constructive critique of the social investment state, see Vandenbroucke and Vleminckx (2011).

${ }^{65}$ Even the Swiss People's Party speaks about the "need to guarantee social security for future generations" (UDC 2013, p. 27) but argues that the best way to do so is through "more market, less bureaucracy, less state regulation" (UDC 2013, p. 29). Regarding childcare, it claims that a child will never feel better than at home with its family (UDC 2013, p. 25).
} 
instance, non-profits) into account in debates or even look to their expertise. Other interviewees stated that non-profit-sector lobbies carry a certain weight in political debates, which would seem to contradict our claim that social policies are above all shaped by state actors and political parties. Indeed, it is clear that the canton and the city often work with non-profit organisations in the field of social policies. But what about the for-profit sector? How mixed is Geneva's welfare system, and what does it indicate about its governance and the distribution of power and type of interaction? And lastly, what about social innovation? Are the local welfare governance arrangements favourable to social innovation?

\subsection{Geneva's Welfare Governance Arrangements: State and Non-Profit Without For-Profit? What About Social Innovation?}

Debates about social innovation have given rise to a large body of literature in the social sciences. The concept itself is ambiguous and has become a confusing "buzzword", as underlined by Moulaert et al. (2013, p. 13):

In our opinion, the lack of clarity about the term "social innovation" can be attributed not only to its evolving analytical status but also to its over-simplistic use as a buzzword in a multiplicity of policy practices associated, for example, with the rationalization of the welfare state and the commodification of sociocultural wellbeing. The appropriation of the term by "caring liberalism", in one of its new incarnations, has added to a Babel-like terminological confusion. (Moulaert et al. 2013, p. 13)

Following the definition of Oosterlynck et al., social innovations are "locally embedded practices, actions and policies that help socially excluded and impoverished individuals and social groups to satisfy basic needs for which they find no adequate solution in the private market or institutionalized welfare policies through processes of social learning, collective action and awareness raising" (2013, p. 4).

So while one important aspect of social innovation is that it occurs on the local level, it must also be understood over a larger scale and be spread by collective action. According to Evers and Ewert, social innovation also involves the novelty of an idea in the given context. Social innovations are ideas, turned into practical approaches; which are new in the context where they appear; attracting hopes for better coping strategies and solutions; marked by a high degree of risk and uncertainty due inter alia to the specific context wherein they appear. [...] Social innovations are, in a significant way, new and disruptive toward the routines and structures prevailing in a given (welfare) system or local setting (Evers and Ewert 2014, p. 11).

It is obvious that what is new in a certain context is not necessarily so in another. As a result, social innovation can be overlooked by researchers if the practice is already well known in other countries or localities. 
In Geneva, the policies analysed by the WILCO project ${ }^{66}$ and the social innovations pursued ${ }^{67}$ reveal a welfare system in which the state (either the canton or the city), and particularly the stakeholders in the public administration, has the predominant role in establishing social policies and concrete programmes, backed (more or less) by the political parties. However, in the matter of the delivery of social services, the state relies on non-profit organisations where possible. These organisations are heavily subsidised, and their rules and programmes are built on those of the public service. Indeed, the Solidarity jobs are subsidised by the canton and located only in non-profit organisations, creating a secondary labour market. Subsidies are therefore given directly to the relevant associations, which execute the decided measure (to give work to long-term unemployed individuals far from the primary labour market). Other programmes and measures, such as the social innovations examined here, reveal the same tendency, where for-profit actors are either absent or marginal. ${ }^{68}$

In contrast, regarding for instance the integration of (young) unemployed individuals, the City of Bern has chosen to build coalitions with economic partners and creates job opportunities in the primary labour market. These public-private partnerships are initiated and coordinated by the state and are a type of "quasi-market solution" ${ }^{69}$ (Felder 2013, p. 25) to unemployment.

In Geneva, the welfare governance arrangements, which favour the interplay between the state and non-profit organisations, and in which economic actors are absent, raise different issues. Battaglini et al. (2001, p. 18) demonstrate the relatively high degree of autonomy of non-profit organisations to realise public policies in the Swiss context. But they also emphasise their weak formal recognition by the state,

\footnotetext{
${ }^{66}$ The policy fields examined by the WILCO project (running time 2010-2013) were childcare, subsidised housing and unemployment.

${ }^{67}$ The three social innovations that were examined during the WILCO project were as follows. (1) The UAC, which is part of the city's Social Service, and which has four offices, located in different areas of the city. Its principal aim is to connect relevant associations with interested participants in civil society and, therefore, to reinforce collective action through better coordination and networking. (2) The ORIF project, an NGO that works to reintegrate young marginalised adults who experience multiple difficulties (health, disabilities, learning problems, etc.) that hinder them from entering the labour market. Support is long term ( 3 years) and multi-dimensional. The project is funded by the Office for Disability Insurance and is therefore a public programme. (3) The Unit for Temporary Housing (ULT) offers subsidised, temporary housing to vulnerable populations, taking into account various dimensions of social marginalisation by offering support from a team employed by the city. More information about these three innovations can be found in the relevant chapter of the e-book of the project (Kakpo and Cattacin 2014, pp. 367-380).

${ }^{68}$ This is the case for the ORIF project (see previous footnote). Its Geneva office, located in Vernier, focuses primarily on education and training rather than on professional integration but with the aim of building partnerships with private enterprises. However, the ORIF project is not specific to Geneva but was instead created by a medical doctor in the Canton of Vaud in 1948 and implemented in nine locations in the French speaking cantons. The office in Vernier opened in 2007 (ORIF 2014).

${ }^{69}$ In fact, the subsidies are part of the wage; for instance, if an individual working in a private company can only work part-time because of a disability, the state provides the other half of the salary. That is why it is only a "quasi-market solution".
} 
not least because of a certain mistrust of these collective actors (2001, pp. 55, 58). Furthermore, non-profit organisations run the risk of being instrumentalised by the state, of being asked to act in neglected fields. Indeed, it is sometimes difficult to clearly define the border separating the state from non-profit organisations, whose intertwined nature contributes to the blurring of that border. For Evers $(2000,2005)$, the borders between the different providers of social services have to be questioned and newly defined, because

changes in the development of welfare states (such as trends towards more autonomy of single service organizations and an increasing intertwining between state and market spheres), linked with a stronger impact of new forms of participation in civil society, have led to a hybridization process in many organizations that provide social services. [...] It is often hard to say where the third sector ends and the public sector begins. Drawing a line between the state-public and the third sector is thus an essentially political task (Evers 2005, p. 745).

In Geneva, it is not so much that the public sector is influenced by non-profit organisations, as it is that non-profit organisations have to adapt to the regulations and logic of the public sector.

So, in a context characterised by a strong state actor, dependent non-profit organisations that tend to be instrumentalised and the clear separation of social policy and private economic activity, what about social innovation?

In the social policies we analysed, ${ }^{70}$ we witness innovation in governance (consultation between the public administration, political parties and non-profit organisations), for instance, for the Solidarity jobs. Regarding the Union for Community Action, ${ }^{71}$ the innovation involves the ways in which users are addressed, regulations and rights, modes of working and financing. But our observations did not reveal innovations in the nature of the local welfare system-for example, outreach to all sectors of the local welfare system, decreased standardisation and increased diversification of welfare arrangements, increased reliance on community components such as families and support networks in mixed welfare systems, the integration of economic and social logics or the integration of welfare and urban politics (Evers and Ewert 2014, pp. 22-24). Furthermore, the instrumentalisation of non-profit organisations by the state is not indicative of a major social innovation because "this instrumentalisation of organisations issued out of civil society runs the risk of destroying their potential for innovation and the renewal of grassroots democracy" (Battaglini et al. 2001, p. 58). ${ }^{72}$

This does not mean that non-profit organisations in Geneva cannot propose any innovative ideas but rather that the canton or city puts its pattern on them. Furthermore, what could be identified as bottom-up initiatives at first glance actually

\footnotetext{
${ }^{70}$ For the innovations investigated by the WILCO project, see footnote 68 .

${ }^{71}$ See footnote 68 .

72 Original quotation: "[...] cette instrumentalisation des organisations issues de la société civile risque de mener à la destruction de leur potentiel d'innovation et de renouvellement de la démocratie de proximité".
} 
correspond to city policy: Citizens are "encouraged" by the city to organise ${ }^{73}$ and express themselves. Since 2008, the City of Geneva has for example set up some "district" or "neighbourhood contracts" that enable people from the area to express themselves in working groups or neighbourhood assemblies. ${ }^{74}$ Or social innovation is linked to citizens' everyday lives, to their active involvement, which is part of the design of the local welfare state and has to be included in the analysis of the governance (Evers 2005). It is not surprising that Geneva has the lowest rate of formal and informal volunteering in Switzerland (Gundelach et al. 2010; Kettenacker and Cattacin 2008; Office fédéral de la statistique (OFS) 2011, pp. 7-10). ${ }^{75}$ Or active citizen involvement is also part of bottom-up initiatives, which are a key component of innovative social policies (Oosterlynck et al. 2013, p. 4).

An interesting hypothesis for this low degree of citizen engagement is the lack of an established city identity, or in other words, "the identity of not having one" (Cattacin and Kettenacker 2011). This could explain why the city tries so hard to provide a link between the citizens and the "international" city.

These considerations lead us to conclude that Geneva's social innovations tend to be incremental and happen above all within state services, and that, because of attempts to control spending, new services are rarely created. Therefore, social innovations tend to be initiated from the top or are quickly regulated and standardised by the state. This state orientation is in line with the key core values of the welfare state as outlined in this chapter. Indeed, we think that the strong state orientation in Geneva, preoccupied by rising inequality over the past two decades (Beer 2013, pp. 35-44), results from its desire to safeguard equality and solidarity among citizens, values that are shared by the stakeholders and political parties. But we also witness state control over social and urban policies and the wish to remain the legitimate source of them.

\subsection{Conclusion}

According to a former state councillor, Geneva's governance is like a machine built by the famous artist Tinguely: "his nuts and bolts are very complex". ${ }^{76}$ In this chapter, we have demonstrated that Geneva's welfare governance follows a more traditional social-welfare policy approach in which the state endorse social responsibility for its citizens and adopts the leading role in the production and distribution of services. Furthermore, political parties and state administration prevail in deciding which social policies are adopted. In this dynamic, economic considerations are

\footnotetext{
${ }^{73}$ An example is the annual Neighbours Day (La fête des voisins). Invitations can be downloaded from the city's website. Neighbours Day began in Paris in 2000 and is now celebrated in 1400 cities in 36 countries). Geneva participated for the first time in 2004 (Ville de Genève 2014b).

${ }^{74}$ For further information, see Ville de Genève (2013).

${ }^{75}$ In general, engagement in informal and formal volunteering is much more important in the Swiss-German parts of the country than in the French-speaking parts.

${ }^{76}$ Public conference, 07.04.2014, University of Geneva.
} 
not related to social policies but handled separately. Furthermore, in its approach to social policies, Geneva focuses on social problems and aims to integrate or include those who suffer from social exclusion, or, even better, to avoid having socially vulnerable individuals become socially excluded..$^{77}$ Key values are equality and solidarity. To fulfil social policies, the state relies essentially on non-profit organisations whose mandates are in accord with the public sector. As a result, non-profits run the risk of being instrumentalised by the state.

In Geneva, it is difficult to implement anything other than incremental social innovation for several reasons. First, conflicts between the two state levels involved in Geneva's governance (overlooking the governance of the Grand Geneve) coupled, second, with the constitutional possibility of vetoes (by the two levels of government and also by popular referendum) are a clear obstacle to social innovation. While Czada (2003, p. 175) argued that these veto-structures are compensated for by a strong, stable, legislative majority, such is no longer the case in Geneva, whose politics are challenged by two "newcomer" parties. Third, moving coalitions in the political arena in recent years and the fact that there is no clear majority often leads to long and heated debates, and we can hypothesise that the consequence is that possible innovations are not adopted in a timely manner. Fourth, a strong state orientation, which excludes partners from the private for-profit sector and whose structures and routines are difficult to change, decreases the likelihood that any social innovations other than incremental ones are adopted and favours "top-down" innovations over "bottom-up" ones. We also witness "weak active citizenship" in Geneva. The question of whether the observed state orientation is responsible for this lack of civil participation or if it is vice versa remains open.

Open Access This chapter is distributed under the terms of the Creative Commons AttributionNonCommercial 4.0 International License (http://creativecommons.org/licenses/by-nc/4.0/), which permits any noncommercial use, duplication, adaptation, distribution and reproduction in any medium or format, as long as you give appropriate credit to the original author(s) and the source, a link is provided to the Creative Commons license and any changes made are indicated.

The images or other third party material in this chapter are included in the work's Creative Commons license, unless indicated otherwise in the credit line; if such material is not included in the work's Creative Commons license and the respective action is not permitted by statutory regulation, users will need to obtain permission from the license holder to duplicate, adapt or reproduce the material.

\section{References}

Armingeon, K., Bertozzi, F., \& Bonoli, G. (2004). Swiss worlds of welfare. West European Politics, 27(1), 20-44. http://www.tandfonline.com/doi/pdf/10.1080/01402380412331280793. Accessed 28 May 2014.

\footnotetext{
77 The distinction between social exclusion and social vulnerability has emerged together with the emergence of the concept of new social risks, which are the most difficult challenge facing welfare systems today. According to Ranci, social vulnerability does not mean permanent poverty but instead "is characterized by instability in a context of harsh constraints. Social vulnerability can be considered as a situation concerning individuals who are at the intersection of risk of poverty, severe material deprivation, and unemployment or inactivity" (Ranci et al. 2014, p. 17).
} 
Battaglini, M., Cattacin, S., \& Tattini, V. (2001). Reconnaissance et coopération: Quelle institutionnalisation de l'associationnisme? Première et Deuxième partie. Associations transnationales/Transnational Associations, 01(2+3), 1-69.

Beer, C. (2013). Ce que cache le Grand Genève. Lausanne: Favre.

Bertozzi, F., \& Bonoli, G. (2003). Federalisme et protection sociale en suisse: Entre immobilisme et innovation. Sociétés contemporaines, 51(3), 13-33. doi:10.3917/soco.051.0013.

Bonoli, G., \& Mach, A. (2000). Switzerland adjustment politics within institutional constraints. In F. W. Scharpf \& V. A. Schmidt (Eds.), Welfare and work in the open economy. Volume II. Diverse responses to common challenges (pp. 131-173). Oxford: Oxford University Press.

Büchi, C. (2012). Genfer Kantonsverfassung. Die missmutige Republik. Neue Zürcher Zeitung. Zürich. http://www.nzz.ch/meinung/kommentare/die-missmutige-republik-1.17683313. Accessed 18 March 2014.

Bütschi, D., \& Cattacin, S. (1993). The third sector in Switzerland: The transformation of the subsidiarity principle. West European Politics, 16(3), 362-379. doi:10.1080/01402389308424979.

Cattacin, S. (1996). Die Transformation des Schweizer Sozialstaates. Überlegungen zu seiner Entwicklungslogik. Swiss Political Science Review, 2(1), 1-14. doi:10.1002/j.1662-6370.1996. tb00166.x.

Cattacin, S. (2006). Retard, rattrapage, normalisation. L'Etat social suisse face aux défis de transformation de la sécurité sociale. Etudes et Sources/Studien und Quellen, 31, 49-77.

Cattacin, S., \& Kettenacker, F. (2011). Genève n'existe pas. Pas encore? Essai sociologique sur les rapports entre l'organisation urbaine, les liens sociaux et l'identité de la ville de Genève. In D. Gaillard (Ed.), Genève à l'épreuve de la durabilité (pp. 29-36). Genève: Braillard.

Cattacin, S., \& Naegeli, P. (2014). Vulnerable migrants: Coping strategies and multiple paths to social exclusion. In C. Ranci, T. Brandsen, \& S. Sabatinelli (Eds.), Social vulnerability in European cities. The role of local welfare in times of crisis. Houndmills: Palgrave Macmillan.

Chapman, M. (2012). Genf torkelt von einem Blödsinn zum nächsten. Der Bund. http://www. derbund.ch/schweiz/standard/Genf-torkelt-von-einem-Bloedsinn-zum-naechsten/story/23611604. Accessed $27 \mathrm{Feb} 2014$.

City of Geneva. (2014). Unité d'action communautaire (UAC). http://www.ville-geneve.ch/ themes/social/action-communautaire-espaces-quartier/unites-action-communautaire-uac/. Accessed 15 March 2014.

Czada, R. (2003). Der Begriff der Verhandlungsdemokratie und die vergleichende Policy-Forschung. In R. Mayntz \& W. Streeck (Eds.), Die Reformierbarkeit der Demokratie. Innovationen und Blockaden (Festschrif., pp. 173-203). Frankfurt: Campus. http://www.politik.uni-osnabrueck.de/POLSYS/Archive/der begriff der verhandlungsdemokratie.pdf. Accessed 20 March 2014.

De Weck, J. (2014). Genève refuse de financer les P + R en France et dit oui aux tarifs TPG. La Tribune de Genève. Geneva. http://www.tdg.ch/geneve/actu-genevoise/geneve-vote-resultats18-mai-direct-hoteldeville/story/16868861. Accessed 22 May 2014.

Dear, M. (1992). Understanding and overcoming the NIMBY syndrome. Journal of the American Planning Association, 58(3), 288-300.

Der Spiegl. (1985). Reich, kultiviert und immer entspannt. Der Spiegel. http://www.spiegel.de/ spiegel/print/d-13515055.html. Accessed 1 July 2014.

Dethurens, C. (2014). Genève: Les Minoteries auront droit à leur grand lifting. Tribune de Genève. Geneva. http://www.tdg.ch/geneve/actu-genevoise/Les-Minoteries-auront-droit-a-leur-grandlifting/story/24023337. Accessed 27 March 2014.

Esping-Andersen, G. (1990). The three worlds of welfare capitalism. Cambridge: Polity Press.

Evers, A. (2000). Les dimensions sociopolitiques du tiers secteur Les contributions théoriques européennes sur la protection sociale et l'économie plurielles. Sociologie du travail, 42 (Editions scientifiques et médicales Elseviers SAS), 567-585.

Evers, A. (2005). Mixed welfare systems and hybrid organizations: Changes in the governance and provision of social services. International Journal of Public Administration, 28(9-10), 737-748. doi:10.1081/PAD-200067318.

Evers, A., \& Ewert, B. (2014). Social Innovations for social cohesions: 77 cases from 20 European cities. In A. Evers, B. Ewert, \& T. Brandson (Eds.), Social innovations for social cohesion. 
Transnational patterns and approaches from 20 European cities (pp. 7-25). Liege: EMES European Research Network asbl. http://www.wilcoproject.eu/ereader-wilco/.

Favre, A. (2013). MCG et UDC, une greffe à l'épreuve des urnes. Le Temps, 30 October. Geneva. http://www.letemps.ch/Page/Uuid/47550e32-40d5-11e3-a9d7-0cbd1678257b/MCG_et_ UDC_une_greffe_à_lépreuve_des_urnes.

Felder, M. (2013). Core values and social innovations in Bern urban welfare system. Master thesis in sociology. Geneva: Department of Sociology.

Francey, O. (2014). Ce qui fait barrage à une traversée lacustre à Genève. Le Temps, 13 February. http://www.letemps.ch/Facet/print/Uuid/6a6eee7e-9422-11e3-a206-e58afd97da78/Ce_qui_ fait_barrage_à_une_traversée_lacustre_à_Genève. Accessed 28 Feb 2014.

Gilliand, P. (1988). Politique sociale en Suisse: introduction. Lausanne: Réalités sociales.

Giraud, O. (2007). La formation comme politique d'activation des chômeurs en Suisse: divergences d'interprétation. Formation emploi (en ligne), 100 (octobre-décembre). http://formationemploi.revues.org/1278.

Grand Genève. (2014a). Grand Genève. Agglomération franco-valdo-genevoise. Chiffres clés. Grand Genève. http://www.grand-geneve.org/grand-geneve/le-territoire/chiffres-cles. Accessed 14 April 2014.

Groupe de travail technique (GTT). (2014). Réforme de la répartition des tâches entre les communes et le canton. ler rapport à l'intention du comité de pilotage. Juin 2014 (pp. 1-19). Geneva. http://www.ge.ch/conseil_etat/2013-2018/communiques/doc/20140701-annexe.pdf. Accessed 3 July 2014.

Gundelach, B., Freitag, M., \& Stadelmann-Steffen, I. (2010). Making or breaking informal volunteering. European Societies, 12(5), 627-652. doi:10.1080/14616696.2010.497224.

Halle, M. (2011). Le droit à l'école pour tous les enfants. REISO/CCSI. http://www.reiso.org/spip. php?article1494. Accessed 12 March 2014.

Hankivsky, O., \& Cormier, R. (2010). Intersectionality and public policy: Some lessons from existing models. Political Research Quarterly, 64(1), 217-229. doi:10.1177/1065912910376385.

Höpflinger, F., \& Wyss, K. (1994). Am Rande des Sozialstaates: Formen und Funktionen öffentlicher Sozialhilfe im Vergleich. Bern: Haupt.

IDHEAP/BADAC. (2010a). Tableaux thématiques BADAC. Finances publiques et redistribution: dépenses par fonction (cantons + leurs communes) en \%. IDHEAP/BADAC. http://www.badac. $\mathrm{ch} / \mathrm{db} / \mathrm{db}$ themes.php?typeN=1\&theme=tableaux\&lang=En-US. Accessed 25 June 2014.

IDHEAP/BADAC. (2010b). Tableaux thématiques BADAC. Finances publiques et redistribution: dépenses par habitant (canton, communes). IDHEAP/BADAC. http://www.badac.ch/db/db.php ?abs $=$ canton_x\&code $=\mathrm{T} 1.57 \&$ annee $=$ max \&arg=\&lang=En-US. Accessed 25 June 2014.

IDHEAP/BADAC. (2010c). Base de données cantons. Finances publiques et redistribution. Redistribution et fiscalité: indice d'inégalité des revenus (Coefficient de Gini). IDHEAP/BADAC.

IDHEAP/BADAC. (2010d). Les tableaux thématiques de la Badac. Santé et sécurité sociale: densité des prestations sociales complémentaires. IDHEAP/BADAC. http://www.badac.ch/db/db .php?abs=canton_x\&code=T1.64\&annee=max\&arg=\&lang=En-US. Accessed 25 June 2014.

IDHEAP/BADAC. (2010e). Tableaux thématiques BADAC. Gouvernance, structures et réformes: départements et services. IDHEAP/BADAC. Accessed 25 June 2014.

Kakpo, N., \& Cattacin, S. (2014). Geneva. In A. Evers, B. Ewert, \& T. Brandsen (Eds.), Social innovations for social cohesion. Transnational patterns and approaches from 20 European cities (pp. 367-380). Liège: EMES European Research Network asbl. http://www.wilcoproject.eu/ ereader-wilco/.

Kazepov, Y. (2010). Rescaling social policies towards multilevel governance in Europe: Some reflections on processes at stake and actors involved. In Y. Kazepov (Ed.), Rescaling social policies: Towards multilevel governance in Europe (pp. 35-72). Vienna: Ashgate Publishing, Ltd.

Kettenacker, F., \& Cattacin, S. (2008). Gouvernance du bénévolat genevois. Quels enjeux, quelles perspectives? Genève: Université de Genève, département de Sociologie.

Klöti, U. (1985). Politische Probleme der Stadt. In Haupt, Schweizerisches Jahrbuch für Politische Wissenschaft. Städte und Agglomerationen (Vol. 25, pp. 13-32). Bern: Haupt. 
Kriesi, H., \& Jegen, M. (2001). The Swiss energy policy elite: The actor constellation of a policy domain in transition. European Journal of Political Research, 39(2), 251-287. doi:10.1023/A:1011032228323.

Kriesi, H., Adam, S., \& Jochum, M. (2006). Comparative analysis of policy networks in Western Europe. Journal of European Public Policy, 13(3), 341-361. http://www.tandfonline.com/doi/ pdf/10.1080/13501760500528803. Accessed 20 March 2014.

Kübler, D. (1995). Problèmes de mise en œuvre de la politique sociale en milieu urbain: l'exemple des services médico-sociaux pour consommateurs de drogues. Swiss Political Science Review, 1(4), 99-120. doi:10.1002/j.1662-6370.1995.tb00459.x.

La Tribune de Genève. (2014). Les Suisses veulent limiter la libre circulation. La Tribune de Genève, 9 February. Geneva. http://www.tdg.ch/suisse/Les-Suisses-veulent-limiter-la-librecirculation-/story/13798297. Accessed 10 Feb 2014.

Les Libéraux-Radicaux de Genève-PLR. (2013). Projet pour Genève (pp. 1-62). Geneva. http:// www.plr-ge.ch/wp-content/uploads/2013/03/Projet-pour-Gen\%C3\%A8ve.pdf.

Les Verts Genevois. (2013). Les Verts Genevois. Objectifs 2013-2018. http://www.verts-ge.ch/ elire-et-voter/elections/cantonales-2013.html. Accessed 5 April 2013.

Mabut, J.-F. (2014). La chasse aux doublons entre les communes et le canton est ouverte. Tribune de Genève, 29 April. pp. 3-4. Geneva.

Mayntz, R., \& Scharpf, F. W. (1995). Der Ansatz des akteurzentrierten Institutionalismus. In R. Mayntz \& F. W. Scharpf (Eds.), Gesellschaftliche Selbstregelung und politische Steuerung (Vol. 23). Frankfurt a. M.: Campus.

Mazzoleni, O. (2008). Nationalisme et populisme en Suisse. La radicalisation de la "nouvelle" $U D C$ (2nd ed.). Lausanne: Presses polytechniques et universitaires romandes.

MCG-Mouvement Citoyen Genevois. (2014a). La charte du MCG. http://mcge.ch/nos-valeurs/. Accessed 5 April 2014.

MCG-Mouvement Citoyen Genevois. (2014b). Bienvenue sur le site officiel du MCG. MCG. http://mcge.ch/. Accessed 21 March 2014.

Merrien, F. X. (1990). Etat et politiques sociales: contribution à une théorie "néo-institutionnaliste.”. Sociologie du Travail, 3, 267-294.

Möckli, S. (1988). Der Schweizerische Sozialstaat. Staat und Politik(Vol. 36). Bern: Haupt.

Moulaert, F., MacCallum, D., \& Hillier, J. (2013). Social innovation: Intuition, precept, concept, theory and practice. In F. Moulaert, D. MacCallum, A. Mehmood \& A. Hamdouch (Eds.), The international handbook on social innovation: Collective action, social learning and transdisciplinary research. Cheltenham: Edward Elgar.

Moulin, M. (2014). Genève déclenche sa chasse aux doublons. Tribune de Genève, 2 July. p. 15. Geneva.

Neidhart, L. (1970). Plebiszit und Pluralitäre Demokratie: Eine Analyse der Funktion des Schweizerischen Gesetzesreferendums (Helvetia Politica. Series B (Vol. 5). Bern: Francke.

Office cantonal de la statistique - OCSTAT/Chancellerie d'Etat. (2012). Elections du Conseil administratif de la Ville de Genève, depuis 1931. Répartition des sièges par parti. http://www. ge.ch/statistique/domaines/17/17_02/tableaux.asp\#18. Accessed 21 March 2014.

Office cantonal de la statistique - OCSTAT/Département des finances. (2013). Informations statistiques. Vie active, emploi et rémunération au travail. 59. http://www.ge.ch/statistique/tel/publications/2013/informations_statistiques/trav_frontaliers/is_trav_frontaliers_59_2013.pdf. Accessed 14 April 2014.

Office cantonal de la statistique - OCSTAT/Chancellerie d'Etat. (2013a). Elections du Grand Conseil, de 1993 à 2013. Répartition des 100 sièges de députés selon le parti. http://www.ge.ch/ statistique/graphiques/affichage.asp?filtreGraph=17_02\&dom=1. Accessed 21 March 2014.

Office cantonal de la statistique - OCSTAT/Chancellerie d'Etat. (2013b). Elections du Conseil d'Etat, depuis 1930. Répartition des 7 sièges, par parti. http://www.ge.ch/statistique/domaines/17/17_02/tableaux.asp\#1. Accessed 21 March 2014

Office fédéral de la statistique (OFS). (2011). Le travail bénévole en Suiss: Comparaisons régionales (pp. 1-20). Neuchâtel: OFS. 
Oosterlynck, S., Kazepov, Y., Cools, P., Wukovitsch, F., Saruis, T., Barberis, E., \& Leubolt, B. (2013). Exploring the multi-level governance of welfare provision and social innovation: Welfare mix, welfare models and rescaling (ImPRovE discussion paper no. 13/12). Antwerp.

ORIF. (2014). En 1948, l'ORIF naissait en terres vaudoises. http://www.orif.ch/espace-decouvrirlorif/organisation/passe-present/. Accessed 20 May 2014.

Parti démocrate chrétien Genève. (2013). Intégrer des associations aux politiques publiques en matière de solidarité. PDC Genève. http://pdc-ge.ch/programme/solidarite/integrer-des-associations-aux-politiques-publiques-en-matiere-de-solidarite/. Accessed 5 April 2014.

Parti socialiste genevois. (2013). Programme de législature 2013-2018. Geneva: Parti socialiste genevois. http://www.ps-ge.ch/programme-2013/. Accessed 5 April 2014.

Pasteur, C., \& Armanios, R. (2011). Les habitants des Grottes se mobilisent contre l'extension de la gare Cornavin. Le Courrier. Geneva. http://www.lecourrier.ch/les_habitants_des_grottes_se_mobilisent_contre_1_e. Accessed 6 April 2014.

Ranci, C., Brandsen, T., \& Sabatinelli, S. (2014). New social risks and the role of local welfare: An introduction. In C. Ranci, T. Brandsen \& S. Sabatinelli (Eds.), Social vulnerability in European cities. The role of local welfare in times of crisis (pp. 3-30). Houndmills: Palgrave Macmillan.

République et canton de Genève. (2007). Votation cantonale du 16 décembre 2007. Canton de Genève. http://www.ge.ch/votations/20071216/cant.asp\#aff. Accessed 5 April 2014.

République et canton de Genève. (2012b). Le Conseil d'Etat. Le pouvoir exécutif. Constitution de la République et canton de Genève du 14 octobre 2012. Canton de Genève. http://www.ge.ch/ conseil_etat/pouvoir_executif.asp. Accessed 21 March 2014.

République et canton de Genève. (2014). Elections. Toutes les élections. http://www.ge.ch/elections/. Accessed 21 March 2014.

République et canton de Genève. Constitution de la République et canton de Genève (2012a). Switzerland. http://www.ge.ch/constitution/doc/nouvelle-constitution.pdf. Accessed 10 Oct 2014.

Sabatier, P. A. (1991). Towards better theories of the policy process. Political Science and Politics, 24(2), 147-156.

Sabatier, P. A. (1998). The advocacy coalition framework: Revisions and relevance for Europe. Journal of European Public Policy, 5(1), 98-130. doi:10.1080/13501768880000051.

Salerno, S. (2013). Pour un vrai bilan des emplois de solidarité. Blog de Sandrine Salerno. http://www.sandrinesalerno.ch/site/2013/09/pour-un-vrai-bilan-des-emplois-de-solidarite/. Accessed 5 April 2014.

Scharpf, F. W. (1985). Die Politikverflechtungsfalle: Europäische Integration und deutscher Föderalismus im Vergleich. Politische Vierteljahresschrift, 26, 323-356.

Scharpf, F. W. (1994). Community and autonomy: Multi-level policy-making in the European Union. Journal of European Public Policy, 1(2), 219-242. http://www.tandfonline.com/doi/ pdf/10.1080/13501769408406956. Accessed 9 Oct 2014.

Scharpf, F. W. (1997). Games real actors play: Actor-centred institutionalism in policy research. Boulder: Westview.

Skenderovic, D. (2009). The radical right in Switzerland: Continuity and change, 1945-2000. New York: Berghahn.

Skenderovic, D., \& D’Amato, G. (2008). Mit dem Fremden politisieren. Rechtspopulismus und Migrationspolitik in der Schweiz seit den 1960er Jahren. Zürich: Chronos Verlag.

Solidarités Genève. (2013). Reprenons nos droits. Elections du Grand Conseil du 6 octobre 2013. http://www.solidarites.ch/geneve/images/stories/2013-elections/ensemble-a-gauche-cantonales-2013-flyer-triptyque-web.pdf. Accessed 5 April 2014.

Swissworld, \& Département fédéral des affaires étrangères. (2014). Genève. Swissworld. http://www. swissworld.org/fr/geographie/villes_suisses/geneve/. Accessed 14 March 2014.

Syndicat interprofessionnel de travailleuses et travailleurs (Sit). (2013). 56e jour de grève des EdS de Partage: Carouge rompt les relations avec Partage. SIT. http:/www.sit-syndicat.ch/spip/ spip.php?article501. Accessed 5 April 2014.

UDC. (2013). Plateforme électorale cantonale de l'UDC Genève. Grand Conseil: législature 2013-2018. http://www.udc-ge.ch/wp-content/uploads/2014/05/Plateforme-\%C3\%A9lectorale-2013-2018. pdf. Accessed 5 April 2014. 
Vandenbroucke, F., \& Vleminckx, K. (2011). Disappointing poverty trends: Is the social investment state to blame? Journal of European Social Policy, 21(5), 450-471. doi:10.1177/0958928711418857.

Ville de Genève. (2013). Historique des Contrats de Quartiers en ville de Genève. Ville de Genève. http://www.ville-geneve.ch/themes/social/action-proximite/contrats-quartier/historique/. Accessed 15 July 2014.

Ville de Genève. (2014a). Genève aujourd'hui en quelques chiffres. Ville de Genève. http://www. ville-geneve.ch/histoire-chiffres/geneve-aujourd-chiffres/. Accessed 14 March 2014.

Ville de Genève. (2014b). La fête des voisins. Ville de Genève. http://www.ville-geneve.ch/themes/ social/manifestations-evenements/fete-voisins/. Accessed 16 March 2014.

Zünd, C. (2014). Cannabis, les volutes de la légalisation. Le Temps. Genève. http://www.letemps.ch/ Page/Uuid/13dc2042-9ff1-11e3-aeb3-dab5266b88a2/Cannabis_les_volutes_de_la_légalisation. Accessed 10 July 2014. 